\title{
Trust: Some Methodological Reflections
}

\author{
DOROTHEA WELTECKE
}

\section{I.}

$\mathrm{W}$ e all know what trust is. We consider trust to play a part in our close relationships, between our friends and loved ones and us. Trust is a ubiquitous element of our everyday life; it is referred to in advertisements, in politics, and in economical contexts. We trust (or do not trust) in God, in the harmlessness of beef, or in the new market (see fig. 1). Despite this seeming self-evidence, however, trust sparks intense scholarly interest. Its nature and finction have been the subject of theoretical and practical analysis in sociology, theology, and philosophy since the beginning of the twentieth century. Interest grew even livelier in the second half of the last century. Challenges such as recent experiences with totalitarian regimes, with intellectual movements like existentialism $^{2}$ and an increasing interest in psychology and sociology, ${ }^{2}$ provoked debates. The massive scholarly literature produced on trust since the 1970s and 1980s until the present is as manifold and diverse as are the different interests of moral philosophers, psychotherapists and economic strategists. ${ }^{3}$

1 O.F. Bounnow, Neue Geborgenheif: Das Problem einer Obenvindung des Exisrentialismus (Stuttgart and Köln, 1955); B. HOMBERG, Hermeneutik des Vertruens: Die philosophisch-pëdogogische Anthropologie O.F. Bollnows, Diss. (M0nster, 1978).

2 R. SCHOTJLANDER, Theorie des Vertrauens (Berlin, 1957); E.H. ERrKSON, Identity and the Life-Cycle (New York, 1959) (Erikson developed the influential concept of 'basic-trust' in this monograph).

3 I am not aware of any general bibliography on trust. The basic make-up of the vast field as well as bibliographical surveys are provided, however, by the increasing number of entries in 
had already started to do precisely what Frevert reconunended and may take the credit for being the first to have worked with Luhmann's theory of trust in historical analysis.?

The significance of trust as a crucial category of everyday life, and also of an expanding field of investigation in the social and economic sciences, is evident. Therefore, there is no need to establish the reasons for the historians' interest in trust. Since they are only just starting to work with the theories, however, some methodological experiments and reflections may be helpful. In some way the late start of the historians may even have its advantages. Since they have not taken part in the debates, theirs could be the detached position of the observer, which might allow for some criticism, and also for some new insights.

II.

Medievalists observe two important deficiencies in the current debates on trust. First, social scientists measure the quantity of trust and analyze why and how trust emerges or disappears. Their results are used to generate political, psychological and economical strategies. These techniques are considered methodologically adequate, because trust is held to be a phenomenon inherent in human nature, which only needs the right conditions and care to blossom. From this perspective, trust is seen as a scarce natural resource. ${ }^{8}$

Problems arise, however, when historians wish to employ trust as a historical category that is independent of the semantic changes of the various historical terms. Trust slips through our hands amorphously as we try to get hold of its exact meaning, and to distinguish it from related ideas and the terms employed to talk about them. We discover that these difficulties are not solved on the level of scientific literature: there are in fact great differences within and between the psychoanalytical, philosophical, theological, sociological and sociopsychological definnitions of trust. Simultaneously, fundamental distinctions

7 P. SCHULIE, "Scripturae publicae creditur": Das Vertrauen in Notariatsurkanden im kommunalen Italien des 12. und 13. Jahrhunderts (Tïbingen, 2003: Bibliothek des Deutschen Historischen Instituts in Rom 101). Forreferences to Luhmann's theories on trust, see infra, note 11.

8 The metaphor of the natural resource is used regularly; there is reason to assume that one has forgotten that it is a metaphor. See, e.g. M. SEIFERT, "Verlust einer risienten Ressource Vextrauensfall im Zuge des ostdeutschen Transfonnationsprozesses", Industrielle Beziehungen: Zeischrift für Arbeit, Organisation und Management 6.2 (1999), pp. 151-190. 
such as, e.g. the difference between trust, faith, hope and reliance, the relation between trust, emotion and rationality or between trust, rationality and ethics remain unclear. Supprisingly, a hundred years of intense research have not achieved even a basic consensus about what trust is. Many contributions to the field therefore start their analysis by stating what 'most' or merely 'many' scholars believe the nature of trust should be.?

If there is no scientific consensus about what trust is, the identification of trust in historical contexts, the historical explanation of its emergence, is simply impossible, despite our street-level certainty. Neither by slavishly following our authorities, nor by the eclectic use of theories can we solve this methodological problem. Besides, the theories are neither historically generated nor are they historically reviewed; their naive use might therefore lead to anachronism. A systematic summary and analysis of the controversies is a pressing desideratum.

Secondly, the assumption that trust is a crucial function of all societies, proved especially fruitful for one specific branch of the sociology and economy of trust. The price paid for this discovery seems to have been a rather equivocal definition: while trust is considered a neutral, technical idea, it is defined as a form, or rather any form, of rational risk management in situations of limited knowledge and control, enhancing the efficiency of cooperation. ${ }^{10}$ This defmition, or rather this common denominator to which different theories have been reduced, differs a great deal from the use of 'trust' in everyday life. This is also twue for the elaborate theories. Neither Luhmann's "mechanism to reduce social complexity"' nor Coleman's morally and emótionally neutral conception of trust $^{12}$ are congruent with the trust Prime Minister Tony Blair and President

9 See, e.g. R. HARDIN, "The street-level epistemology of trust', Analyse und Kritik 14 (1992), pp. 152-176, at p. 152: "A widely held view is that tnust and distrust are essentially rational"; N. BRAUN, "Altruismus und Vertrauen", Analyse und Kritik 14 (1992), pp.-177-186, at p. 177: "Vertrauen ist nach Ansicht vieler Sozialwissenschaftler..."; see also JONES, "Trust", p. 465: "Most people writing on tust accept the following claims...".

10 Cf. Gi onva, "Vertrauen", p. 988: "Gemeinsamer Nenner ist-ausgehend von philosophischen und soziologischen Bestimmungen des Vertrauens im 20. Jahutundent - die Auffassung von Vertrauen als Sich-Verlassen aufein Gegenûher angesichts eines ungewissen und risikohaften Ausgangs einer Handlung unter freiwilligem oder erzwungenem Kontrollverzicht".

"N. LusmanN, Vertraren: Ein Mechanismus der Raduktion sozialer Komplexität, 3rd edn. (Stuttgart, 1989; original edition 1968). Translation: N. LUtUMANN, "Trust: A mechanism for the reduction of social complexity", tr. H. DAVIS, J. RAFUMAN and K. ROONEY, in: Truest and Power, ed. T. BURNs and G. PoGGi (Chichester; NY, 1973), pp. 4-103.

12 J. COLEMAN, Foundations of Social Theory (Cambridge, MAss., 1990). Both Luhmann's and Coleman's thoughts are constantly reviewed and continually developed; see, e.g. Norm, Herrschafi und Vertrauen: Beiträge zu James S. Colemans Grundlagen der Sozialtheorie, ed. H.P. MOLIER and M. SCHMIDT (Opladen, 1998); H. HARDIN, "Street-level epistemology", and 
George W. Bush referred to between autumn 2002 and 2003. Other obvious examples come to mind.

On the other hand, there are existing discourses in political strategies of the twentieth century, especially in authoritarian and dictatorial contexts, which could be disqualified as not being discourses about tust - which they positively are - but discourses about slavish obedience, naive loyalty, authoritarian power, and unscrupulous manipulation - which they also are. That is to say, historical discourses about trust, e.g. in the Soviet Union or in the German Empire during the last years of the First World War, ${ }^{13}$ do not fit into the framework of values and conceptions that modem scientific discourses about trust in Western Europe and America take for granted: these are human rights, representative democracy with its means of institutional security and control, and moderate capitalism. ${ }^{14}$ Inherent in the sociological idea of trust is the notion that trust is notbinding in a juridical sense, and, different from other forms of risk-management by means of power, law or money, that there are no (juridical) sanctions for a breach of trust. The implementation of existing theories to discourses different from the Westem and democratic discourses of trust might cause distortions. But the modem origins of the trust theories and their consequences are not taken into account - quite the contrary. ${ }^{\text {is }}$

Can something on which so little consensus is possible, which is thought to exist in contexts as different as those between Führer and people, between individual businessman and global management, or between mother and infant, be a natural phenomenon 'as such' at all? On the contrary, the seeming identity between quite different phenomena is obviously the result of using the same tenn for them. This hypothesis is supported by the fact that ever more hybrid terms are now needed to distinguish between matters which are indeed felt to be different phenomena, like Freundschaftsvertrauen ('trust in friendship'), Systemvertrauen ('trust in systems'), Urvertrauen ('basic trust'), etc. ${ }^{16}$

other essays in the issue of Analyse und Kritik in which his essay appeared.

13 A. SCFMIDT, "Eine Stwatsfihnung in der Vertravenskrise: Deutschland 1918", in: Vertrauen: Historische Annäherungen, pp. 279-305; J.C. BERRENDS, "Soll und Haben: Freundschafisdiskurs und Vertraucnsressourcen in der stalesozialistischen Diktatur", ibid,, pp. 336364; see also T. KüঙกE, "Vertrauen und Kameradschaft: Soziales Kapital im 'Endkampf' der Webrmacht", ibid., pp. 245-278.

14 E.g. F. FUXUYAMA, Trust: The Social Virtues and the Creation of Prosperity (New York, 1996); Vertrauen: Die Grundlage des sozialen Zusammenhalis, ed. M. HARTMANN, C. OFFE (Frankfur 2001); see also supra, note 3.

is See also the critique of O.G. OExIE, "Luhmanns Mittelalter: N. Luhmarn, Gesellschaftsstrukar und Semantik, Bd. 3", Rechwhistorisches Journal 10 (1991), pp. 53-66.

is See, e.g. GloJna, "Vertrauen". 
It is true that the sociology of trust points towards a very important social phenomenon: people rely on each other. But the reality of the disputes about the nàture of trust, and the reality of the differences between specific forms of relying on one another, disguised by the use of identical labels, support the hypothesis that trust is culturally and specifically constructed. Today - and this is an intriguing historical fact in itself - there even exist ideas of trust which are the exclusive product of scientific debates. ${ }^{17}$ Consequently, trust is an object of historical transformation. Just as it is the custom to distinguish between fides in the Roman Empire and fides in the Germanic fealty, without assuming the existence of something like fides as such, trust as such does not exist.

III.

Trust, as we have seen, is commonly thought of as an unhistorical element of social life. It may have been labelled with different terms, but it remained the same. While this assurnption was never historically reviewed, let alone historically proven, the present discourse of trust is also closely linked with conceptions of history, and especially with those of modem history.

Cases in point are the theories of trust of Georg Simmel ${ }^{18}$ and Niklas Luhmann. ${ }^{19}$ They agree that trust has become an important social factor only in modern societies. Simmel said that trust.was necessary because of a lack of knowledge. He suggested that in modem societies knowledge about other people was decreasing, because he experienced modem societies to be too complex and too liberal, while people were too individual to know everything about each other. An individual represents many personalities in the different situations and societies he or she inds himself or herself in; the inner intentions, however, remain hidden from view. Here, trust is deeply attached to the modem idea of individuality and the limits of communication.

Niklas Luhmann constructed his theory of trust from similar assumptions. He observed that over-complexity does not prevent psychologically stable people from coping with the danger of using a car, or from cooperating with strangers, because the individual understands that he or she does not need to control, to understand, to foresee everything. Individuals delegate functions.

17 See above, notes 11-13.

18 G. SOMMeL, "Das Geheimnis und die geheime Gesellschaft", in: ID., Soziologie: Untersuchungen über die Fornen der Vergesellschafiung (Frankfurt am Main,

19 LUHMANN, Vertrauen. 
Their lack of knowledge is bridged by trust and in this way complexity is reduced. Through cooperation individuals multiply their own potentials and by that increase complexity again. Luhmann imagined our modern economical and social societies with their interdependent institutions as skyscrapers constructed on skeletons of trust. How accurately his metaphor describes the mechanism of the globalized world became apparent when two real skyscrapers collapsed in 2001.

While Simmel and Luhmann's analyses of their own time produce fruitful insights, they combined their theories with pseudo-historical theories about past, so-called 'traditional' societies. These theories were pseudo-historical in nature because they were constructed without empirical data. Traditional societies were a simple antitype of Simmel and Luhmann's idea of the modern world. Intimacy and familiarity were seen as their main characteristics. In traditional societies, people relied on each other as a matter of course. There were no individuals, no complexity, no unknown future, therefore no secrets, no risks and no trust. Luhmann's argumentation suggests that his 'traditional society' is to be understood as the 'precartesian society', ${ }^{20}$ i.e., probably, the Middle Ages.

Here the medievalists' reviewing of the theories and pragmatic analysis could start. As Petra Schulte has shown, trust can be seen to operate, in ways analogical to those of Luhmann's world, in the Italian communal life of the twelfth and thirteenth centuries. ${ }^{21}$ It is true that, in commerce and on joumeys, mistrust was often the order of the day. But since it was impossible to control, to know, and to understand everything, and since there was the need to reduce over-complexity in medieval worlds, too, people were in fact relying on one another, be it on the validity of their acts and charters, the quality of unfamiliar money, the expertise of priests and scholars, the loyalty of subordinates or friends, the correct transmission of money from Europe to the Holy Land or the experience of the seafarer. There were also different ways of managing the risk involved in relying on somebody else, whether in personal, political or religious relations. This is why there are so many historical studies about social conflict and social cohesion which could be reread fruitfully from the perspective of trust. ${ }^{22}$ But should they perhaps not only be reread but also be rewritten?

20 LUHMANN, Vertrouen, p. 21.

2t SCHULTE, "Scripturae publicae creditur".

23 E.g. N. OHLER, Reisen im Mittelalter (München, 1986); G. ALTHOFF, Verwandte, Freunde und Getreue: Zum politischen Stellenwert der Gruppenbindungen im fïhen Mittelalter (Darustadt, 1990); V.EPP, Amicitia: Zur Geschichtepersonaler, sozialer, politischerundgeistlicher Beziehungen im fï̌hen Mittelalter (Stuttgart, 1999); K. GöRICH, Die Ehre Friedrich Barbarossas: Kommunikation, Konflikt und politisches Handeln im 12. Jahrhundert (Dammstadt, 
Otto Gerhard Oexle for one already voiced systematic and empirical criticism against the pseudo-historical constructions of the 'traditional societies' ${ }^{23}$ This romantic antitype is instructive only about the roots of the discourse about trust in the modern world ${ }^{24}$ Consequently, while it is plausible that the increase of social complexity in social systems is concomitant with an increasing employment of trust, Simmel and Luhmann's explanations for the emergence of trust are mere guesswork; they are not historically valid. Complexity and integration might have been the cause, not the effect, of what they defined as trust. And certainly an increase of cultural knowledge and a levelling of cultural differences is as much part of the modern world as is the highly idealized conception of individuality.

IV.

The title of an early modern travel story shows that changes both in tust as a term for a specific idea as well as in the different forms of understanding relationship and reliance are probable, even during the modern era:

2001); G. SIGNORt, Versorgen, Vererben, Erinnem: Kinder- und familienlose Erblasser in der städtischen Gesellschafi des Spätmittelalters (Göttingen, 2001). This selection of recommended books does not claim to be representative.

${ }^{23}$ E.g. O.G. Oexze, "Das Bild der Moderne vom Mittelalter und die modeme Mittelalterforschung", Frühmittelalterliche Studien 24 (1990), pp. 1-22; 10., “Das Mittelalter und das Unbehagen der Moderne: Mittelalterbeschwörungen in der Weimarer Republik und danach", in: Spannungen und Widersprïche: Gedenkschrift für František Graus, ed. S. BURGHARTZ et al. (Sigmaringen, 1992), pp. 125-153; and ID., "Das Mittelaiter und die Moderne: Eine folgenreiche Problemgeschichte', in: Mittelalter und Modeme: Entdeckung und Rekonstruktion der mittelalterlichen Welt, ed. P. SEGL (Sigmaringen, 1997), pp. 307-364.

24 In this context an observation of Gunilla-Friederike Budde comes to mind, who, in another set of theories on trust, discovered equally romantic images: the family as a refuge and the origin of trust as such (G.-F. BUDDE, "Familienvertrauen - Selbstvertrauen - Gesellschaftsvertrauen: Pädagogische Ideale und Praxis im 19. Jahrhundert", in: Vertrauen: Historische Annäherungen, pp. 152-184, at pp. 152-153. Budde explicitly refers to A. GIDDENs, The Consequences of Modemity (Cambridge, 1990), B. BARBER, The Logic and Limits of Ihust (New Brunswick and New York, 1983), and B. MISZTAL, Trust in Modern Societies: The Search for the Bases of Social Order (Combridge, 1996). These (mainly psychological and modernist) theorems, which originated in a discourse about trust in educational theories (BUDDE, "Familienvertrauen", pp. 155-161) are not congruent with Luhmann's theories, because they equate familiarity and trust. Luhmann, however, stresses the difference between these two concepts and saw trust as the more reflected and elaborate form of reliance (LUHMANN, Vertrauen, pp. 17-33). 
The perillous and most unhappy voyages of Jobn Struys, through Italy, Greece, Lifeland, Moscovia, Tarary, Media, Persia, East-India, Japan, and other places in Europe, Africa and Asia: containing I ... II. A due description of the several cities, towns, forts and places of trust, as to their site and strength, fortifications by nature, or art, etc. with other things worthy of note; and III. An exact memorial of the most disastrous calamities which befell the author in those parts (viz.) by ship-wrack, robberies, slavery, hunger, tortures, with other incommodities and hardships ...25

'Places of trust' are not included in the sociological and psychological theories of trust. These places have to do with the problem of power and violence, not with knowledge. Power, on the other hand, is strangely absent from the sociological and psychological debates, although it has been very prominent in the political talk about trust in the twentieth century. ${ }^{26}$

A history of the term 'trust' has not been written as yet. Apparently, the English etymology still poses problems. They cannot be solved in the present paper. ${ }^{27}$ But it is clear that 'trust' and Vertrauen have the same roots. Together with a bundle of other terms, they probably origin from the Indo-European root *deru-('oak' or 'tree'), which meant 'strong', 'solid like a tree'. To this family also belongs Middle High German trûunge, which since the sixteenth century is a term for marriage. 'To trust', in German vertrauen, is related to trauen, which means both 'to trust' and 'to marry'. It is also related to Old English and German Trost, which originally meant 'to become solid'. ${ }^{28}$ In modem German, Trost is simply a synonym for 'consolation' and 'comfort', while it is apparently no longer in use in English. ${ }^{29}$ Accordingly, Middle High German missetriuwe is not simply a term for 'mistrust', but also includes the semantic field of 'not solid', 'to be desolate', 'to be in despair'.

2S J. STRUYS, tr. J. MORRISON (London, 1683). There have been several editions.

${ }^{26}$ See supra, n. 13.

27 "Trust", in: J.A. SIMPSON and E.S.C. WEINER, The Oxford English Dictionary 18 (Oxford, 1989), pp. 623-625, and in: The Oxford Dictionary of English Etymology, ed. C.T. ONIONS, with the assistance of G.W.S. FRIEDRICHSEN and R.W. BuRCKFFELD (Oxford, 1966), p. 946.

${ }^{28}$ See also "trust, trusten, tristi, onustri, mustmen", in: R. LEWIS et al, Middle English Dictionary, 6 (Ann Aubor, 1995), pp. 1137-1140, at pp. 1140-1142, pp. 1142-1144, pp. 1144 1145, p. 1145.

29 "Vertraueg", in: G. DRosDowsKI, Duden: Das Herkunfowörterbuch: Etymologie der deutschen Sprache (Mannheim etc., 1997: Duden 7), pp. 754-755. This passage summarizes WELTECKE, "Vertrauen", pp. 73-81.

${ }^{30}$ F. OHLY, "Missetriuwe, 'desperatio': Mittelhochdeutsche Worter fur die thoologische Verzweiffung", Zeitschriff für deutsche Philologie 110 (1991), pp. 321-336; M. LEXER, Mittelhochdeutsches Wörterbuch, 1 (Leipzig, 1872), pp. 2171-2172. 
The Old German synonyms for vertrauen are not confmed to the terms just mentioned. Vertrauen apparently is based on semantic change and confluence of a great variety of tenns: Fidunge, gedranc, getriuwe, getriuwunge, getrûwen, hoffenunge,

gewinnen. ${ }^{31}$ Several of these terms are semantically related to the binding formal contract, duty, law, and the coniuratio. In this sense, they greatly differ from sociological definitions of trust, which are characterized by infonnality. Again, the meaning 'to marry' is found in the sample.

Matthias Lexer wrote his renowned dictionary of Middle High Gennan in the second half of the nineteenth century. Reading his entries on trust, it becomes apparent that his semantic understanding of vertrauen is neither congruent with contemporary German nor with the sociological definitions. ${ }^{32}$ Even within the last 130 years important changes in the semantic field took place. ${ }^{33}$ Lexer saw vertrauen as a term for making a contract or taking an oath. He also felt that vertrauen means 'to entrust'. While 'entsust' is semantically dominant in English 'trust' ('trustee'), this semantic field is no longer included in present Gennan vertrauen.

A Latin synonym for 'trust' suggested by the dictionaries is fides. And it is true, often translating fides by 'trust' is quite correct. In many respects, however, both the ancient and medieval fides differ greatly from modem ideas of trust, because of the differing ethical and juridical meanings inherent in the Latin word. ${ }^{34}$ Fides was a category in symmetrical and asymmetrical relations. Synonyms for fides in other classical languages are, e.g. Greek pistis, Hebrew 'émunä(h), and Arabic 'imā̄n. ${ }^{35}$ Despite their different cultural and religious

31 "Vertrauen", in: E. KOLLER, W. WEGSIBIN and N.R. WOLF, Neuhochdeutscher Index zum miltelhochdeutschen Wortschak (Stuttgart, 1990), p. 470; see also p. 185, "Gottvertrauen", p. 374 "Selbstvertrauen".

32 LEXER, Mittelhochdeutsches Wörterbuch, 3 (Leipzig, 1878), p. 277.

33 See also FREVERT, "Spurensuche", pp. 13-20.

34 C. BeCKER, "Fides", in: Realenzytlopädie fir Antike und Christentum 7 (Stuttgatt, 1969), pp. 801-839; K.-J. HOLLKESKAMP, "Fides - deditio in fidem - dextra data et accepta: Recht, Religion und Ritual in Rom", in: The Roman Middle Republic: Politics, Religion, and Historiography, c. 400.133 B.C., ed. C. BRUTIN (Rome, 2000), pp. 223-250.

35 See, e.g. E. GRUEN, "Greek Tistiç and Roman fides", Athenaeum N.S. 60 (1982), pp. 5068; D. LOHRMANN, "ristis im Judenæum", Zeitschrift für die neutestamentliche Wissenschafi 64 (1973), pp. 19-38; A. JEPSEN, "Jok", in: Theologisches Worterbuch zum Alten Testament, ed. H.J. FABRY, 1- (Stuttgart, 1973-), 1, pp. 313-348 (with bibliographical references); I. ABRAHAMr, J. HABERMANN and Ch. MANERIN, "Belief", in: Encyclopardia Judaica, 2nd edn., ed. F. SKoLNIK and M. BERENRAUM, 22 vols. (Detroit etc., 2007), 1, pp. 290-294; L. GARDET, "'imān", in: The Encyclopedia of Islam, 2nd edn. ed. H.A.R. GiBg et al., 1-(Leiden, 1960-), 3 (1971), pp. 1170-1174. 
origins, these terms are semantically very similar. They are much closer related to one another than to 'trust'. One important semantic feature they share is that they all are synonyms for 'religious belief'. Apparently there are ideas which link medieval Europe with the Near East, and separate them from the modem discourses for reasons which might be an object of historical research.

'Religious belief' subsumed the meaning 'to abide by a specific (religious, ethical, political) law'. 'Belief' is also closely related to 'faithfulness'. In this sense, all these tenns are also related to 'truth', as abiding by the law is seen as 'doing the truth'. The Semitic terms even share the same root with their respective tenns for 'truth'. These different aspects are mirrored by the words which are used to translate fides into Gcrman. When the late-eighth-century translator of the seventh-century De fide catholica contra Iudeos by Isidore of Sevilla (c. 570-636) translated the word fides, he used triuuua, which is 'faithfulness', chilaubin, which is 'belief', and chilaupnissa, which is 'confession', doctrina fidei. ${ }^{36}$

Temns which do not have the same prominent religious connotations are of course confido, confidentia and fiducia. But these terms are no synonyms of 'trust' in the modem sense either. Fiducia includes a wide semantic field to which belong 'courage' and 'strength'. Philological research has also shown that these terms are rather ambivalent, different from fides, which is almost exclusively seen as a positive category. They can also mean 'audacity', even 'hubris' ${ }^{37}$ And they are no basic categories for interpersonal relations as fides had been ${ }^{38}$ or trust has become.

\section{V.}

Bible translations fonn a very useful corpus of sources, which has been intensely investigated by philologists. They connect the ancient and the modem world and supply us with materials which can be followed up into other genres. Surprisingly and significantly, however, 'trust' as a biblical term has not elicitod much interest so far, neither from philological nor from theological scholarship. The reason is obvious: in the Bible, 'trust' is neither important, nor

${ }^{36}$ H. EGGERS, Vollständiges lateinisch-althochdeutsches Wörterbuch zur althochdeutschen Isidor-Ubersetzang (Betlin, 1960).

${ }^{37}$ L.J. ENGELS, "Fiducia", in: Reallexikon für Antike und Christentum 7 (Stuttgart, 1969), pp. 839-877.

${ }^{38}$ EPP, Amicitia, p. 4. 
especially fiequently used - quite the contrary. Although the text is not medieval in a strict sense, a test drill in Martin Luther's German translation of the Bible helps to illustrate the problem to some extent. Martin Luther's employment of Vertrawen as verb and substantive in the Old Testament was compared with the original Hebrew and with the Vulgate and Medieval German translations respectively. ${ }^{39}$ The findings can be summarized as follows.

Luther uses vertrawen very rarely, especially when compared to the frequency of the term in present-day Germany. Significantly, the use of the term increased in contemporary German revisions of his translation. ${ }^{40}$ Originally it occurs just about 50 times in the entire text. ${ }^{4 !}$ Vertrawen as a rule does not wanslate fides, émunāa (h) or pistis. In the Old Testament, it represents Hebrew $b a \vec{t} t a h$ and ḩăsäh, ${ }^{42}$ which in the biblical context mean 'to be confident', but also 'to flee into security'. ${ }^{43}$ That is to say, Vertrawen, just as the above-mentioned 'places of rust' our unhappy voyager referred to, have a substratum linking them to the existential problems of violence, war, security and power. This is quite different from risk-management. The assumption that this semantic field is indeed inherent in Vertrawen is supported by an English parallel: While Luther translates Ps 118, 8 and 118, 9 "Es ist gut auff den HERRN vertrawen ...", a twentieth-century English translation has "It is better to find refuge in the Lord ....,4

Luther's use was more or less congruent with the medieval use of the German terms getruwen and férsehen, but vertrawen had already expanded seman-

39 The following results summarize WELTECKE, "Vertrauen", pp. 81-88. The Old German versions used were Notker, Psalmen nach der Wiener Handschrift, ed. R. HEINZEL and W. SCHERER (Straßburg, 1876) and Zwei Psalter aus dem 14. Jahrhundert (Dresden Ms. M287 und Hamburg in scr. 142) und drei verwandie Bruchstücke ous Schleiz, Breslou und Düsseldorf, ed. H. EGGERS (Berlin, 1962).

${ }^{40}$ Die Bibel nach der Übersetzung Martin Luthers, ed. Deutsche Bibelgesellschaft (Stuttgart, 1984).

4M. LUTHER, Diegantze Heilige Schrifft Deudsch, letzte zu Luthers Lebzeiten erschienene Ausgabe, ed. H. VoLZ with the assistance of H. BLANKEand F. KUR (Wittenberg, 1545; reprint München, 1972).

42 But not always; cf. "הоח", in: G. LISOWsKy, Konkordanz zum hebräischen Alten Testament (Stuttgart, 1958), pp. 209-210, 514.

${ }^{43}$ A. JEPSEN, "בּ (bātah)", in: Theologisches Wörterbuch zum Alten Testament, l (1973), pp. 608-615; J. GAMBERON, "הOח (hāsāh)", in: Theologisches Wörterbuchzum Alten Testament, 3 (1982), pp. 71-83.

${ }^{44}$ The New English Bible: The Old Testament (Oxford and Cambridge, 1970). Concerning some reflections on Luther's rather negative attitude towards "Vettrauen" in people in the context of the semantic field 'to find refinge, to body', see WELTECKE, “Vertrauen”, p. 87. 
tically. It also seems to have included gehoffen and gedingen, i.e. 'to hope' and 'to be committed to somebody' respectively. Luther also uses vertrawen in the sense of 'to marry', 'to engage', as the semantic field of the word had been in Middle High German. ${ }^{45}$ But Vertrawen in his understanding can also mean 'obligation', 'duty', and even 'power of one person over another': “... ki 'ānōkit bä'alin bakem ..." or "quia ego vir vester", as the Lord says in Ier 3, 14, is translated by Luther as "... ich wil euch mir vertrawen ...". In this passage, for once we understand that Luther has in mind something that is essentially different from our understanding of 'trust'. Although phonetically virtually identical, the sense of vertrauen has radically changed. This is why in the modernised translation vertrawen in this passage has been substituted. Instead we fmd "... denn ich bin euer Herr?", which reads like a literal translation of the Vulgate, rather than Luther's rendering of the prophet's words.

VI.

Through conflict regulation and integration, people in the Middle Ages developed social structures which enabled them to rely on one another. This kind of reliance, however, was not necessarily understood as 'trust' is today. 'Trust' can be seen as a specific combination of cultural practices, of emotional and rational phenomena, and of specific ideas and values connected with these practices and phenomena. Theories of trust might serve as a tool to become aware of the human ability to cooperate. But a history of trust should investigate these matters from more than one perspective and with a consideration of more than just one term, 'trust'. Such a history should show how this cultural idea came into being, how and why trust discourses helped to shape the identity of the modern world, and why the tern denotes - and by that identifies - matters as different as loyalty, cooperation, security and courage, to name just a few things. A history of trust should explain why, despite important changes and diversity, and despite its ideological and strategic use and misuse, trust managed to obscure its history to such an extent that it now seems a natural phenomenon.

45 See supra, n. 30. 
392

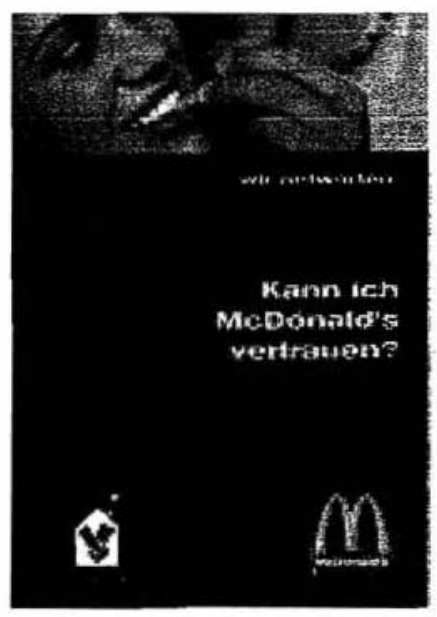

Fig. 1 A current example of the strategic use of 'trust'. 